\title{
高齢心不全入院患者と担当理学療法士の考える 退院支援に対する必要性の差異に関する調査
}

\author{
$\mathrm{Q}$ 分類法による分析 \\ Survey of Elderly Heart Failure Patients and Physical Therapists \\ on Discharge Support Needs: Analysis by Q-sort Method
}

井上 宜充 ${ }^{1)}$ 隆島 研吾 ${ }^{2)}$ 高木 峰子 ${ }^{2)}$ 島津 尚子 ${ }^{2)}$

Yoshimitsu INOUE, RPT $^{1)}$, Kengo TAKASHIMA, RPT ${ }^{2)}$, MineKo TAKAGI, RPT ${ }^{2)}$, NAOKO SHIMAZU, RPT ${ }^{2)}$

${ }^{1)}$ Department of Rehabilitation Services, Yokosuka General Hospital Uwamachi: 2-36 Uwamachi, Yokosuka-shi, Kanagawa 238-8567, Japan TEL +81 46-823-2630 E-mail: yoshimitsui@jadecom.jp

2) Department of Physical Therapy, Kanagawa University of Human Services

Rigakuryoho Kagaku 34(1): 61-68, 2019. Submitted Jul. 30, 2018. Accepted Sep. 17, 2018.

\begin{abstract}
Purpose] To survey the characteristics and differences of discharge support that heart failure patients and physical therapists consider necessary. [Participants and Methods] The subjects were 16 patients with heart failure who were 65 years of age or older and 7 physical therapists (PT). The Q-sort method was used to survey the values relating to discharge support needed by heart failure patients. [Results] The discharge support item considered highly necessary by both groups was "response at times of recurrence." Differences between the two groups were found in "purpose of exercise" and "explanation of exercise risk", with the patient group expressing lower need than the PT group. [Conclusion] Both groups were conscious of the need for effective management of salt and water intake, and body weight for prevention of recurrence. The need for "exercise" was lower in the patient group than in the PT group. This suggests that there is a problem with guidance related to exercise.
\end{abstract}

Key words: elderly heart failure patients, physical therapist, discharge support

要旨: [目的]初回心不全で入院中の患者と担当理学療法士が必要と考える退院支援の特性と差異を調査すること.〔対 象と方法」対象は 65 歳以上の心不全初回入院患者 16 名とその担当理学療法士 7 名とした. 本研究では Q 分類法を 使用し心不全患者が必要とする退院支援に関する価值観を調査した。〔結果〕両群ともに必要性が高いとした退院支 援は「再発時の対応」であった。両群で差異を認めたのは「運動の効果目的」と，「運動のリスク説明」で患者群の 必要性は理学療法士群に比べ低かった。〔結語〕本研究の結果から両群ともに再発予防のために塩分・水分・体重の 管理が効果的であることを意識していた．理学療法士群に比べ患者群では「運動」に関する必要性が低く，今後運動 に関連した指導への課題があることが示唆された.

キーワード：高龃心不全患者，理学療法士，退院支援

\footnotetext{
1) 横須賀市立うわまち病院 リハビリテーション科：神奈川県横須賀市上町 2-36（テ238-8567）TEL 046-823-2630

2) 神奈川県立保健福祉大学 理学療法学科

受付日 2018 年 7 月 30 日 受理日 2018 年 9 月 17 日
} 


\section{I. はじめに}

厚生労働省の患者調査によると日本の心不全患者数は 年々増加し，平成 8 年に 20 万人であった患者数は平成 26 年には 30 万人を超えている。平成 26 年における日 本の肺炎患者数 6 万 9 千人と比較し, 心不全患者の総数 が非常に多いことがわかる，また，全心疾患に対する心 不全患者の割合は，平成 8 年に $9 \%$ であったが平成 26 年には $15 \%$ となり, 増加の一途をたどっている1).

日本の心不全大規模疫学調査の結果から心不全患者は 高齢者が多いことが明らかとなっており，平均年齢 \pm 標準偏差は JCARE-CARD（National and design of Japanese Cardiac Registry of Heart Failure in Cardiology) では $71.0 \pm 13.4$ 歳 ${ }^{2)}$, CHART-1 (Analysis of chronic heart failure registry in the Tohoku district) では $68.7 \pm$ 13.4 歳 3$),$ CHART-2 では $68.9 \pm 12.3$ 歳と報告されて いる4)。また，JCARE-CARD では退院後 6 力月以内の 再入院率が $27 \%$ と心不全は再入院率が高くなっている2).

心不全患者 82 名を対象とした後方視的調査では，心 不全患者の平均年齢は $80.9 \pm 12.6$ 歳と報告され，前述 の疫学調査以上に高齢化が進んでいる状況が示されてい る。また, 調査対象の $46 \%$ が心不全増悪による再入院 患者であり, JCARE-CARD 同様に再入院率が高い.さ らに,これらの高齢心不全患者は入院時にすでに要介護 認定者である割合が $42 \%$ であることに加え，入院時に 歩行不可であった割合は $46 \%$ と報告されている。この 調査では前述のとおり心不全患者の高齢化と要介護者の 増加から, 高齢心不全患者では日常生活活動（Activities of Daily Living：以下，ADL）能力の再獲得や退院支援 が必要であると結論づけている5)。これは，心不全患者 に対し心臓リハビリテーションの必要性は当然のこと, 高齢入院患者としての理学療法介入や退院支援の必要性 が高いことを示唆している。しかし，心不全患者に対す る退院支援に関する先行研究は，涉編する限り散見され る程度である。

心不全で入院加療する高齢者は肺炎と比較して多く, さらに経時的増加傾向を示し再入院率が高い. 高齢心不 全患者やその家族にとって, 自宅退院のための決断や準 備行動には困難を伴うため退院支援が必要となる。高齢 心不全患者の退院支援は，多職種による包括的な介入が 必要であり，理学療法士の役割も重要と考えられるが, この領域の理学療法研究はほとんど存在しない.心不全 により入院した高齢患者やその家族が，自宅退院のため の準備をする過程においてどのような退院支援を望んで いるのか，そして退院支援に関する様々なカテゴリにお いて理学療法士が退院支援として重視している点につい て明らかになっていないことが問題であると考える。

また，心不全という疾患に限らず現在までに報告され ている患者が必要とする退院支援の調査・研究は多くの
場合，質問紙による調査や少数例へのインタビューと いった手法で実施されている 6-8)，そのため，これらの 結果は患者の退院支援に関するニーズや価值観が断片的 に抽出された可能性が高く，個人の価值観を包括的に把 握することはできていないと推測される。

心不全患者への退院支援については，患者が求める支 援のみではなく，理学療法士が必要と考える支援に関す る実態との差異を確認する必要もある。これらの患者・ 理学療法士それぞれの必要と考える退院支援の特性と差 異を明らかにすることにより，理学療法士が効果的に提 供できるための退院支援のあり方を分析することは，心 不全患者の予後に関しても有意義と考えられる.

本研究の目的は入院前の ADL が自立し, 初回の心不 全で入院加療を必要とする高齢患者が初めての心不全入 院を経験する際に，患者本人，担当理学療法士のそれぞ れが必要と考える退院支援の特性と両者の差異について 明らかにし，理学療法士が提供するより良い退院支援の あり方の一助にすることである.

\section{II. 対象と方法}

\section{1. 対象}

本研究の対象者は, 神奈川県横須賀市内 2 病院の心不 全入院患者およびその担当理学療法士とした．対象の適 応基準は入院時 65 歳以上の心不全入院患者であり，入 院前の ADL は自立し，かつ認知症によるADL 制限も ない者とした。理学療法士は年齢や経験年数の制限はな く，当該患者の入院中の担当理学療法士とした。また理 学療法士については, 異なる複数名の対象患者を担当し ている場合に繰り返しの参加を可能とすることとし，患 者と担当理学療法士は対応関係にある設定にした.

本研究は対象者への文書説明を行い，文書同意を得た うえで実施した。また，研究機関の神奈川県立保健福祉 大学研究倫理審査委員会（承認番号：保大第 10-49), 研究実施機関の横須賀市立うわまち病院倫理委員会（承 認番号：2017002），横須賀市立市民病院倫理委員会（承 認番号：市民倫理発第 28-7 号）の承認を受け実施した。

\section{2. 方法}

個人や集団の価值観の観測方法に Q 分類法がある ${ }^{9)}$. 現在までに研究利用されている $\mathrm{Q}$ 分類の手法は Stephenson ${ }^{10)}$ による方法論が基にされている，Q分類 は多くの変数（価值観の全体像から構成される各項目） を個人が考える必要性・重要性に応じて優先順に並び替 えて観測データとするため, その変数の優先順（パター ン）が個人の価值観を包括的に反映するものである。こ の測定手法を用いることにより，数多くある退院支援の 項目について, 個人の「必要な退院支援」「不要な退院 支援」という価值観を包括的に捉えることが可能と考え 
られる。

本研究はこの Q 分類法を使用し, 心不全患者が必要 な退院支援に関する価值観の横断的調査・分析をした。 $\mathrm{Q}$ 分類法は退院支援に必要と考えられる項目が書かれた 数十枚のカードを, 対象者が $\mathrm{Q}$ 分類盤という盤上に価 值観の必要性や重要性に応じた配置場所と枚数に従って 並び替えを行い，価值観を測定する，本研究は，患者が 特に不安を感じていると予測される入院初期段階におい て必要な退院支援について調查をするために, 入院後 2 週間以内に調查を実施することとした。

まず， Q分類法で使用するカード（以下， Q 分類セッ 卜）の作成を行った。カードには 1 枚ごとに病院におい て患者や家族に提供される退院支援の項目が記載されて いる. $\mathrm{Q}$ 分類セット構築のための項目（以下，カード内 容）は診療報酬制度に抢ける退院支援に関連する項目, 日常生活活動評価（Barthel Index）の各項目，日本国内 の先行研究・ガイドライン等から抽出した. 先行研究の 検索は医学文献検索サイト医学中央雑誌 (医中誌) を使 用して「退院, 高齢, 心不全, リハビリ，患者心理，家 族心理」をキーワードとして組み合わせて検索した。検 索された文献から理学療法領域に限らず患者または家族 の必要とする退院支援に関する項目を抽出した．抽出さ れた退院支援の個別項目は70項目であり，これを重複 や偏りがなく, 全範囲に及ぶように, 経験のある理学療 法士 3 名により 35 項目を選択した。 これらの 35 項目 について, さらに分類の適正さと価值観の全体像を網羅 することができているかを検討する作業をしたうえで, この 35 項目を内容・種別ごとに 9 つに分類した（表 1).

分類は「疾患の説明 (3 項目)」, 「生活指導 (4 項目)」, 「理学療法の説明 (5 項目)」, 「日常生活活動 (9 項目)」, 「退院調整 (7 項目)」, 「生活の広がりと社会復帰 (4 項 目)」,「服薬管理 (1 項目)」, 「食事 ·栄養管理 (1 項目)」, 「精神面へのサポート (1 項目)」の全 9 分類 35 項目 (35 枚のカード）とした，作成したカードはプレテストとし て 65 歳以上の健常高齢者 4 名と経験年数 19 年目の理 学療法士 1 名への $\mathrm{Q}$ 分類を実施した。患者 1 名に対す る $\mathrm{Q}$ 分類の実施時間は平均 12.3 分 (7 分 35 秒 18 分 38 秒）であった。 また，カード内容の可読性や医学的 知識のない高齢者でも理解できる文章であることを確認 し，プレテストの意見を基に必要に応じてカード文章の 表現を修正し，完成したカードセットを本研究の調查で 使用した。

$\mathrm{Q}$ 分類の実施方法は次のように行った. $\mathrm{Q}$ 分類セット を持った対象者はカードの内容を確認しながら優先順位 の高いものを $\mathrm{Q}$ 分類盤上の右列から順に左列に並べて いった（図 1). 列ごとにカードを配置する枚数は決め られており, 列ごとに $-4 \sim+4$ 点までの 9 段階の点数 が振られている，縦の並び順は優先順位を考慮しなかっ た．並ベたカード配置と点数が個人の価值観のプロファ

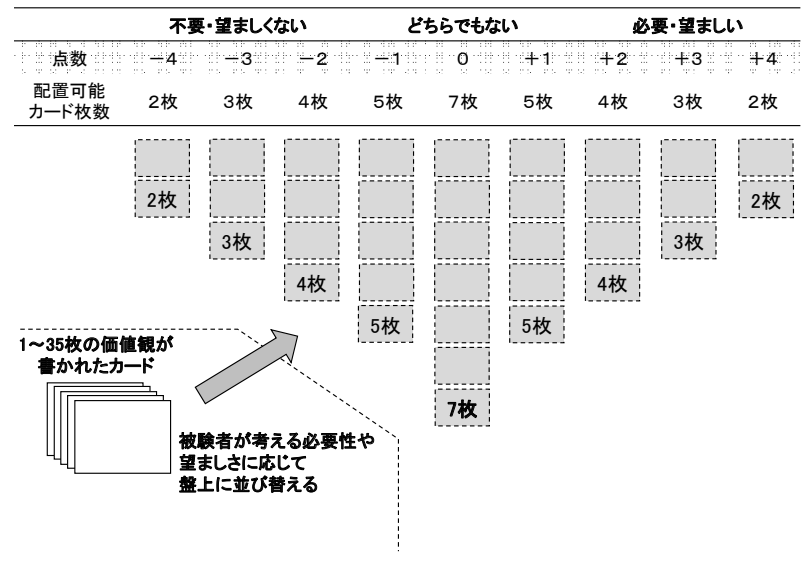

図1 Q 分類盤 (カード35枚の場合の模式図)

イルとなる。カード配置を強制的に正規分布させるため， 必然的に個人のカード配置の合計点は 0 点で, すべての 対象者で等分散のデータが得られる。この手法は点数の 合計点の大小ではなく, 各項目の重みを分析する調査手 法ということができる.

得られたデータの解析は次のように行った。各群にお いて「+4, +3，-4，-3」の配点をされた項目の度 数（人数）を集計し，これを結晶化とした．結晶化とい う解析方法については岡本9)の方法を参考にした。 $「+4$, $+3 」$ の度数が多い項目（カード）はその群に打いて退 院支援として必要性が高いことを示す。「-4, $-3 」 の$ 度数が多い項目（カード）はその群に打いて退院支援と して必要性が低いことを示す，Q分類法では提示した優 先順位のうち両端（上位と下位）の項目を価值観の「結 晶化」として分析することで集団の価值観の特徽を解釈 する。

また，Q分類を測定手法として得られる $-4 \sim+4$ ま での 9 段階の点数について, 各カードに対する患者群と 理学療法士群の中央值と四分位範囲を算出し, 2 群間の 比較をした。比較にはWilcoxon の符号順位検定を使用 した，有意水準は $5 \%$ とした。解析ソフトはエクセル統 計（SSRI）を使用した。

\section{III. 結 果}

本研究に扔いて実際にサンプリングした対象者は 32 名（患者 16 名, 担当理学療法士 16 名）とした（表 2 ）. 患者群は男性 12 名, 女性 4 名, 平均年齢 \pm 標準偏差 は $72.8 \pm 6.3$ 歳, 入院時 NYHA の分類は正度が 5 名, $\mathrm{IV}$ 度が 11 名, 平均在院日数 \pm 標準偏差は $17.4 \pm 10.2$ 日，障害高齢者の日常生活自立度は J1 以下が 15 名，J2 が 1 名, 認知症高齢者の日常生活自立度は I 以下 16 名 であった．理学療法士群は延べ人数 16 名であるが対象 者数は 7 名であり, 男性 3 名, 女性 4 名, 平均年齢 \pm 
表 $1 \mathrm{Q}$ 分類 カードセットの分類とカード文章

\begin{tabular}{|c|c|c|}
\hline 分類 & 項目名 & カード文章 \\
\hline \multirow[t]{2}{*}{ 疾患の説明 } & $\begin{array}{l}1 \text { 心不全の一般知識 } \\
2 \text { 患者本人の病状説明 }\end{array}$ & $\begin{array}{l}\text { 入院する原因となった病気に関する医学的かつ一般的な説明 } \\
\text { 患者さんおよび家族に対する患者さん本人の病気の状況に関 } \\
\text { する説明 }\end{array}$ \\
\hline & 3 心不全の予後説明 & 今後, 患者さん本人の病気や症状はどうなるのかの説明 \\
\hline \multirow[t]{4}{*}{ 生活指導 } & 4 喫煙・飲酒のリスク説明 & 喫煙・飲酒が病気に与える影響に関する説明・指導 \\
\hline & 5 適切な生活様式 & 心臓に負担のかからない適切な生活様式に関する説明・指導 \\
\hline & 6 感染症予防 & $\begin{array}{l}\text { 肺炎などを引き起こすような感染症の予防に関する説明・指 } \\
\text { 導 }\end{array}$ \\
\hline & 7 再発時の対処 & $\begin{array}{l}\text { 退院後に再び病気が悪化した時はどのような症状がみられる } \\
\text { のか？どのように対処すれば良いのか教えて欲しい. }\end{array}$ \\
\hline \multirow[t]{5}{*}{ 理学療法の説明 } & 8 運動の効果 ·目的 & 運動の効果や目的に関する説明 \\
\hline & 9 リハビリ目標 & 患者さん本人のリハビリの目標についての説明 \\
\hline & 10 リハビリ予後 & $\begin{array}{l}\text { 患者さん本人が将来的にリハビリでどこまで身体機能や生活 } \\
\text { 能力が改善するかの説明 }\end{array}$ \\
\hline & 11 退院後のリハビリ & $\begin{array}{l}\text { 自宅で実施できる自己リハビリの方法またはリハビリテー } \\
\text { ションサービスを退院後も継続的に受ける方法についての説 } \\
\text { 明・指導 }\end{array}$ \\
\hline & 12 運動のリスク & 運動の注意点に関する説明・指導 \\
\hline \multirow[t]{9}{*}{ 日常生活活動について } & 13 食事動作 & $\begin{array}{l}\text { 患者さんの食事動作に関する現状の説明，介助方法の説明， } \\
\text { 入院中の練習 }\end{array}$ \\
\hline & 14 整容動作 & $\begin{array}{l}\text { 患者さんの整容動作に関する現状の説明，介助方法の説明， } \\
\text { 入院中の練習 }\end{array}$ \\
\hline & 15 移乗動作 & $\begin{array}{l}\text { 患者さんの車椅子やトイレへの乗り移り動作に関する現状の } \\
\text { 説明, 介助方法の説明, 入院中の練習 }\end{array}$ \\
\hline & 16 更衣動作 & $\begin{array}{l}\text { 患者さんの着替え動作に関する現状の説明，助方法の説明， } \\
\text { 入院中の練習 }\end{array}$ \\
\hline & 17 入浴・清潔 & $\begin{array}{l}\text { 患者さんの入浴・清潔動作に関する現状の説明, 介助方法の } \\
\text { 説明, 入院中の練習 }\end{array}$ \\
\hline & 18 トイレ動作 & $\begin{array}{l}\text { 患者さんのトイレ動作に関する現状の説明, 介助方法の説明, } \\
\text { 入院中の練習 }\end{array}$ \\
\hline & 19 排泄管理 & $\begin{array}{l}\text { 患者さんの排泄管理に関する現状の説明，介助方法の説明， } \\
\text { 入院中の練習 }\end{array}$ \\
\hline & 20 歩行・移動 & $\begin{array}{l}\text { 患者さんの歩行・移動動作に関する現状の説明, 介助方法の } \\
\text { 説明, 入院中の練習 }\end{array}$ \\
\hline & 21 階段動作 & $\begin{array}{l}\text { 患者さんの階段動作に関する現状の説明，介助方法の説明， } \\
\text { 入院中の練習 }\end{array}$ \\
\hline \multirow[t]{7}{*}{ 退院調整 } & 22 退院前カンファレンス & $\begin{array}{l}\text { 自宅退院のために病院と介護事業所や在宅医療の職員と本 } \\
\text { 人・家族が合同で方針などを話し合う }\end{array}$ \\
\hline & 23 自宅環境整備 & $\begin{array}{l}\text { 本人, 家族の負担を減らすための自宅環境の調整・整備に関 } \\
\text { するアドバイ }\end{array}$ \\
\hline & 24 介護者の健康状態 & 家族の健康管理についてのアドバイス \\
\hline & 25 福祉用具 & 福祉用具の準備・使用法に関する助言 \\
\hline & 26 介護サービス & 介護保険制度・サービスの利用に関する助言 \\
\hline & $\begin{array}{l}27 \text { 自宅を想定したADL 訓 } \\
\text { 練・指導 }\end{array}$ & $\begin{array}{l}\text { 自宅生活を具体的に想定した日常生活動作の指導・練習およ } \\
\text { び生活様式に関するアドバイス. 入院中に自宅や病院外の環 } \\
\text { 境で実際に動作を確認するなどの対応をして欲しい. }\end{array}$ \\
\hline & 28 介護事業所への引き継ぎ & 病院と介護サービス事業所の情報の引継ぎ \\
\hline \multirow[t]{4}{*}{ 生活の広がりと社会復帰 } & 29 社会復帰 & 患者さんの社会復帰のための助言・指導 \\
\hline & 30 趣味活動 & 患者さんの趣味活動についての助言・指導 \\
\hline & 31 外出·交通機関の利用 & 公共の交通機関の利用についての助言・指導 \\
\hline & 32 社会的課題解決 & 社会的課題解決のための支援 \\
\hline 服薬管理 & 33 薬に関する説明・指導 & 薬の効果・服用方法・注意点の説明・指導 \\
\hline 栄養管理 & 34 食事に関する説明・指導 & 塩分·水分 · 体重管理についての食事指導 \\
\hline 精神面へのサポート & 35 精神面へのサポート & 患者さんの抑うつや不安など精神症状に対するサポート \\
\hline
\end{tabular}


表 2 対象者の基本属性

\begin{tabular}{|c|c|c|}
\hline & 心不全患者群（n=16） & $\begin{array}{c}\text { 理学療法士群 }(n=7) \\
\text { 延べ人数 } 16 \text { 例 }\end{array}$ \\
\hline 性別（男性／女性） & $12 / 4$ & $3 / 4$ \\
\hline 年齢（歳） & $72.8 \pm 6.3$ & $29.0 \pm 5.2$ \\
\hline 疾患情報 & & - \\
\hline 入院時 NYHA（人） & III $: 5, \quad$ IV $: 11$ & \\
\hline 入院時 $\mathrm{BNP}(\mathrm{pg} / \mathrm{mL})$ & $799.9 \pm 896.2$ & \\
\hline 入院時 左室駆出率（\%) & $40.4 \pm 12.8$ & \\
\hline 在院日数（日） & $17.4 \pm 10.2$ & - \\
\hline 要介護度（人） & 無: 15 , 支援 $2: 1$ & - \\
\hline 障害高齢者の日常生活自立 & $\mathrm{J} 1$ 以下 : $15, \mathrm{~J} 2: 1$ & - \\
\hline 認知症高齢者の日常生活自立度 & I 以下 : 16 & - \\
\hline \multirow[t]{4}{*}{ 同居人数（人） } & 同居人数 0 人 : 3 & - \\
\hline & 同居人数 1 人 : 11 & \\
\hline & 同居人数 2 人 : 1 & \\
\hline & 同居人数 3 人 : 1 & \\
\hline 飲酒歴（有：人） & 10 & - \\
\hline 喫煙歴（有：人） & 10 & - \\
\hline 職業 & 無職 : 11 , 在職 : 5 & - \\
\hline 理学療法士としての経験年数（年） & & $5.9 \pm 4.5$ \\
\hline 心臓リハビリテーションの経験（満年数） & - & $4.3 \pm 2.1$ \\
\hline
\end{tabular}

平均值 \pm 標準偏差. NYHA：New York Heart Associationの心機能分類, BNP：脳性ナトリウ ム利尿ペプチド.

標準偏差は $29.0 \pm 5.2$ 歳, 理学療法士の平均経験年数 \pm 標準偏差は $5.9 \pm 4.5$ 年であった.

患者群の結晶化結果（表 3）では「必要」とされた退 院支援の上位 5 項目が「再発時の対処」,「食事指導」, 「心不全の予後」，「心不全に関する一般的知識」，「感染 症の予防」であり,「不要」とされた退院支援の上位 5 項目が「食事動作」,「整容動作」,「移乗動作」,「入浴 · 清潔」,「趣味活動」および「社会的課題解決」(同順位) であった。

理学療法士群の結晶化結果（表 3）では「必要」とさ れた退院支援の項目の上位 5 項目が「運動のリスク説 明」,「再発時の対処」, 「症例の病態説明」,「薬に関する 説明・指導」，「食事に関する説明・指導」であり，「不 要」とされた上位 5 項目が「整容動作」,「病院と介護事 業所の引き継ぎ」,「食事動作」,「排泄管理」,「福祉用具 の準備・使用法」であった。

各項目の中央值の結果（表 4）から, 「疾患の説明」, 「生活の広がりと社会復帰」,「服薬管理」,「栄養管理」, 「精神面へのサポート」の分類の各項目では 2 群間の統 計学的な有意差を認めなかった.

「理学療法の説明」の分類では「運動の効果・目的」, 「運動のリスク説明」の中央值は患者群に比べ理学療法 士群が有意に高かった。

「日常生活活動」の分類では「移乗」,「更衣」,「トイ レ動作」,「排泄管理」の中央值は理学療法士群に比へ患
者群が有意に高かった.

「退院調整」の分類では「退院前カンファレンス」,「福 祉用具の準備・使用法」,「病院と介護事業所の引き継 ぎ」の中央值は理学療法士群に比べ患者群が有意に高 かった．「自宅生活を具体的の想定した ADL」の中央值 は患者群に比べ理学療法士群が有意に高かった。

\section{IV. 考 察}

患者群の結晶化結果では「必要」とされた退院支援の 上位 5 項目が「再発時の対処」，「食事に関する説明・指 導」,「心不全の予後説明」,「心不全の一般知識」,「感染 症予防」であった。本研究の対象は心不全初回入院患者 であり, 初めての心不全発症・入院という状況において その知識が十分でないことは明らかであり, 疾患に関す る知識や再発予防のための指導を求めている様子がうか

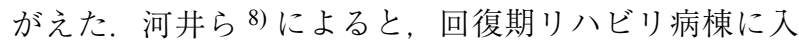
院する脳血管疾患・大腿骨頸部骨折の患者を対象にした 調査で, 患者が入院中に不安と感じる要因は病気や障害 の見通しに関する不安であり, 疾病管理・再発予防・教 育のための支援を求めているとしている。，心不全患者に おいて同様の調査・分析はされていないが, この点にお いて心不全患者も同様に入院中に不安を感じて支援を求 めているものと予測される。またTsuchihashi ら 11)に よると, 心不全再発原因の 1 位は塩分・水分制限の不徹 
表 3 結晶化の結果

\begin{tabular}{|c|c|c|c|c|c|c|c|c|c|c|c|c|c|c|c|c|c|}
\hline & & & 心 & 不 & 全 & 患 & 者 & \multicolumn{2}{|c|}{ 群 } & & 理 & 学 & 療 & i & 士 & \multicolumn{2}{|c|}{ 群 } \\
\hline 分類 & No. カード項目名 & \multicolumn{2}{|c|}{+4 点 } & \multicolumn{2}{|c|}{+3 点 } & \multicolumn{2}{|c|}{-3 点 } & \multicolumn{2}{|c|}{-4 点 } & \multicolumn{2}{|c|}{+4 点 } & \multicolumn{2}{|c|}{+3 点 } & \multicolumn{2}{|c|}{-3 点 } & \multicolumn{2}{|c|}{-4 点 } \\
\hline \multirow{3}{*}{ 疾患の説明 } & 1 心不全の一般知識 & 3 & $(19 \%)$ & 3 & $(19 \%)$ & 0 & $(0 \%)$ & 0 & $(0 \%)$ & 3 & $(19 \%)$ & 5 & $(31 \%)$ & 1 & $(6 \%)$ & 0 & $(0 \%)$ \\
\hline & 2 患者本人の病状説明 & 2 & $(13 \%)$ & 4 & $(25 \%)$ & 0 & $(0 \%)$ & 1 & $(6 \%)$ & 5 & $(31 \%)$ & 3 & $(19 \%)$ & 1 & $(6 \%)$ & 0 & $(0 \%)$ \\
\hline & 3 心不全の予後説明 & 4 & $(25 \%)$ & 2 & $(13 \%)$ & 0 & $(0 \%)$ & 1 & $(6 \%)$ & 5 & $(31 \%)$ & 1 & $(6 \%)$ & 0 & $(0 \%)$ & 0 & $(0 \%)$ \\
\hline \multirow{4}{*}{ 生活指導 } & 4 契煙·飲酒のリスク説明 & 0 & $(0 \%)$ & 1 & $(6 \%)$ & 3 & $(19 \%)$ & 1 & $(6 \%)$ & 0 & $(0 \%)$ & 1 & $(6 \%)$ & 1 & $(6 \%)$ & 0 & $(0 \%)$ \\
\hline & 5 適切な生活様式 & 1 & $(6 \%)$ & 4 & $(25 \%)$ & 1 & $(6 \%)$ & 0 & $(0 \%)$ & 0 & $(0 \%)$ & 3 & $(19 \%)$ & 0 & $(0 \%)$ & 0 & $(0 \%)$ \\
\hline & 6 感染症予防 & 3 & $(19 \%)$ & 3 & $(19 \%)$ & 1 & $(6 \%)$ & 0 & $(0 \%)$ & 1 & $(6 \%)$ & 0 & $(0 \%)$ & 0 & $(0 \%)$ & 2 & $(13 \%)$ \\
\hline & 7 再発時の対処 & 4 & $(25 \%)$ & 5 & $(31 \%)$ & 0 & $(0 \%)$ & 0 & $(0 \%)$ & 3 & $(19 \%)$ & 6 & $(38 \%)$ & 0 & $(0 \%)$ & 0 & $(0 \%)$ \\
\hline \multirow{5}{*}{ 理学療法の説明 } & 8 運動の効果 ·目的 & 0 & $(0 \%)$ & 0 & $(0 \%)$ & 1 & $(6 \%)$ & 2 & $(13 \%)$ & 3 & $(19 \%)$ & 2 & $(13 \%)$ & 0 & $(0 \%)$ & 0 & $(0 \%)$ \\
\hline & 9 リハビリ目標 & 0 & $(0 \%)$ & 0 & $(0 \%)$ & 2 & $(13 \%)$ & 0 & $(0 \%)$ & 1 & $(6 \%)$ & 2 & $(13 \%)$ & 0 & $(0 \%)$ & 0 & $(0 \%)$ \\
\hline & 10 リハビリ予後 & 1 & $(6 \%)$ & 1 & $(6 \%)$ & 0 & $(0 \%)$ & 1 & $(6 \%)$ & 0 & $(0 \%)$ & 0 & $(0 \%)$ & 0 & $(0 \%)$ & 0 & $(0 \%)$ \\
\hline & 11 退院後のリハビリ & 0 & $(0 \%)$ & 0 & $(0 \%)$ & 0 & $(0 \%)$ & 0 & $(0 \%)$ & 0 & $(0 \%)$ & 4 & $(25 \%)$ & 0 & $(0 \%)$ & 0 & $(0 \%)$ \\
\hline & 12 運動のリスク & 2 & $(13 \%)$ & 1 & $(6 \%)$ & 0 & $(0 \%)$ & 1 & $(6 \%)$ & 4 & $(25 \%)$ & 5 & $(31 \%)$ & 0 & $(0 \%)$ & 0 & $(0 \%)$ \\
\hline \multirow{9}{*}{$\begin{array}{l}\text { 日常生活活動に } \\
\text { つて }\end{array}$} & 13 食事動作 & 0 & $(0 \%)$ & 1 & $(6 \%)$ & 5 & $(31 \%)$ & 2 & $(13 \%)$ & 0 & $(0 \%)$ & 0 & $(0 \%)$ & 5 & $(31 \%)$ & 4 & $(25 \%)$ \\
\hline & 14 整容動作 & 0 & $(0 \%)$ & 0 & $(0 \%)$ & 4 & $(25 \%)$ & 2 & $(13 \%)$ & 0 & $(0 \%)$ & 0 & $(0 \%)$ & 8 & $(50 \%)$ & 3 & $(19 \%)$ \\
\hline & 15 移乗動作 & 0 & $(0 \%)$ & 1 & $(6 \%)$ & 1 & $(6 \%)$ & 3 & $(19 \%)$ & 0 & $(0 \%)$ & 0 & $(0 \%)$ & 5 & $(31 \%)$ & 0 & $(0 \%)$ \\
\hline & 16 更衣動作 & 0 & $(0 \%)$ & 0 & $(0 \%)$ & 2 & $(13 \%)$ & 0 & $(0 \%)$ & 0 & $(0 \%)$ & 0 & $(0 \%)$ & 5 & $(31 \%)$ & 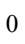 & $(0 \%)$ \\
\hline & 17 入浴 · 清潔 & 0 & $(0 \%)$ & 1 & $(6 \%)$ & 1 & $(6 \%)$ & 3 & $(19 \%)$ & 0 & $(0 \%)$ & 0 & $(0 \%)$ & 1 & $(6 \%)$ & 0 & $(0 \%)$ \\
\hline & 18 トイレ動作 & 0 & $(0 \%)$ & 1 & $(6 \%)$ & 1 & $(6 \%)$ & 1 & $(6 \%)$ & 0 & $(0 \%)$ & 0 & $(0 \%)$ & 5 & $(31 \%)$ & 0 & $(0 \%)$ \\
\hline & 19 排泄管理 & 1 & $(6 \%)$ & 0 & $(0 \%)$ & 2 & $(13 \%)$ & 1 & $(6 \%)$ & 0 & $(0 \%)$ & 0 & $(0 \%)$ & 5 & $(31 \%)$ & 3 & $(19 \%)$ \\
\hline & 20 歩行 - 移動 & 1 & $(6 \%)$ & 2 & $(13 \%)$ & 1 & $(6 \%)$ & 0 & $(0 \%)$ & 0 & $(0 \%)$ & 0 & $(0 \%)$ & 0 & $(0 \%)$ & 0 & $(0 \%)$ \\
\hline & 21 階段動作 & 0 & $(0 \%)$ & 0 & $(0 \%)$ & 0 & $(0 \%)$ & 0 & $(0 \%)$ & 0 & $(0 \%)$ & 0 & $(0 \%)$ & 0 & $(0 \%)$ & 0 & $(0 \%)$ \\
\hline \multirow{7}{*}{ 退院調整 } & 22 退院前カンファレンス & 0 & $(0 \%)$ & 2 & $(13 \%)$ & 1 & $(6 \%)$ & 0 & $(0 \%)$ & 0 & $(0 \%)$ & 0 & $(0 \%)$ & 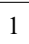 & $(6 \%)$ & ? & $(13 \%)$ \\
\hline & 23 自宅環境整備 & 0 & $(0 \%)$ & 1 & $(6 \%)$ & 3 & $(19 \%)$ & 0 & $(0 \%)$ & 0 & $(0 \%)$ & 1 & $(6 \%)$ & 0 & $(0 \%)$ & 0 & $(0 \%)$ \\
\hline & 24 介護者の健康状態 & 0 & $(0 \%)$ & 0 & $(0 \%)$ & 0 & $(0 \%)$ & 1 & $(6 \%)$ & 0 & $(0 \%)$ & 0 & $(0 \%)$ & 0 & $(0 \%)$ & 0 & $(0 \%)$ \\
\hline & 25 福祉用具 & 0 & $(0 \%)$ & 1 & $(6 \%)$ & 3 & $(19 \%)$ & 1 & $(6 \%)$ & 0 & $(0 \%)$ & 0 & $(0 \%)$ & 2 & $(13 \%)$ & 4 & $(25 \%)$ \\
\hline & 26 介護サービス & 0 & $(0 \%)$ & 2 & $(13 \%)$ & 3 & $(19 \%)$ & 0 & $(0 \%)$ & 0 & $(0 \%)$ & 0 & $(0 \%)$ & 1 & $(6 \%)$ & 2 & $(13 \%)$ \\
\hline & $27 \begin{array}{l}\text { 自宅を想定した } \\
\text { ADL 訓練・指導 }\end{array}$ & 1 & $(6 \%)$ & 0 & $(0 \%)$ & 2 & $(13 \%)$ & 2 & $(13 \%)$ & 0 & $(0 \%)$ & 3 & $(19 \%)$ & 0 & $(0 \%)$ & 0 & $(0 \%)$ \\
\hline & 28 介護事業所への引き継ぎ & 0 & $(0 \%)$ & 0 & $(0 \%)$ & 3 & $(19 \%)$ & 1 & $(6 \%)$ & 0 & $(0 \%)$ & 0 & $(0 \%)$ & 2 & $(13 \%)$ & 8 & $(50 \%)$ \\
\hline \multirow{4}{*}{$\begin{array}{l}\text { 生活の広がりと } \\
\text { 社会復帰 }\end{array}$} & 29 社会復帰 & 0 & $(0 \%)$ & 0 & $(0 \%)$ & 0 & $(0 \%)$ & 1 & $(6 \%)$ & 1 & $(6 \%)$ & 0 & $(0 \%)$ & 1 & $(6 \%)$ & 0 & $(0 \%)$ \\
\hline & 30 趣味活動 & 1 & $(6 \%)$ & 0 & $(0 \%)$ & 1 & $(6 \%)$ & 3 & $(19 \%)$ & 0 & $(0 \%)$ & 0 & $(0 \%)$ & 0 & $(0 \%)$ & U & $(0 \%)$ \\
\hline & 31 外出 · 交通機関の利用 & 0 & $(0 \%)$ & 0 & $(0 \%)$ & 2 & $(13 \%)$ & 1 & $(6 \%)$ & 0 & $(0 \%)$ & 1 & $(6 \%)$ & 1 & $(6 \%)$ & 2 & $(13 \%)$ \\
\hline & 32 社会的課題解決 & 0 & $(0 \%)$ & 2 & $(13 \%)$ & 1 & $(6 \%)$ & 3 & $(19 \%)$ & 0 & $(0 \%)$ & 1 & $(6 \%)$ & 1 & $(6 \%)$ & 1 & $(6 \%)$ \\
\hline 服薬管理 & 33 薬に関する説明 · 指導 & 2 & $(13 \%)$ & 3 & $(19 \%)$ & 1 & $(6 \%)$ & 0 & $(0 \%)$ & 1 & $(6 \%)$ & 6 & $(38 \%)$ & 0 & $(0 \%)$ & 1 & $(6 \%)$ \\
\hline 栄養管理 & 34 食事に関する説明·指導 & 4 & $(25 \%)$ & 4 & $(25 \%)$ & 0 & $(0 \%)$ & 0 & $(0 \%)$ & 2 & $(13 \%)$ & 6 & $(38 \%)$ & 0 & $(0 \%)$ & 0 & $(0 \%)$ \\
\hline $\begin{array}{l}\text { 精神面への } \\
\text { サポート }\end{array}$ & 35 精神面へのサポート & 0 & $(0 \%)$ & 3 & (19\%) & 1 & (6\%) & 0 & $(0 \%)$ & 0 & $(0 \%)$ & 3 & (19\%) & 1 & (6\%) & 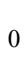 & (0\%) \\
\hline
\end{tabular}

度数（割合：度数 / 16 例\%）

底，2位が感染症とされており，本研究の結果から初回 入院の心不全患者において再発予防のための意識は高く 心不全特有の支援を求めていることが確認できた。

一方で「不要」とされた退院支援の上位 5 項目は「食 事動作」, 「整容動作」, 「移乗動作」, 「入浴・清潔」, 「趣 味活動」および「社会的課題解決」であった。 Goodlin ${ }^{12)}$ によると心不全患者の病期と身体機能の関係 は, 心不全の再発を繰り替えしながら経時的に身体機能 が低下するとされている。本研究の対象は心不全初回入 院かつ入院前の ADL 能力が自立している者であり, ADL に関する支援は不要とするのは当然と考えられる。 心不全初回入院患者だけを対象とした退院支援に関する 報告はされておらず，本研究の結果から心不全初回入院 患者の退院支援に関する価值観を把握することができ た。 また，加齢や再発とともに身体機能が低下すること
で必要となる退院支援は初回入院時とは異なる可能性が 高く, 今後は異なる年齢層や病期の患者を対象とした調 査も必要となると考えられる。理学療法士を含め医療従 事者が提供する退院支援は時期に応じた内容であること が重要である.

理学療法士群の結晶化結果では「必要」とされた退院 支援の項目の上位 5 項目が「運動のリスク」,「再発時の 対処」,「患者本人の病態説明」,「薬に関する説明・指 導」，「食事に関する説明・指導」であった。 心不全とい う疾患の特徵の一つは再発する可能性が高いことであ る. 理学療法士群は運動・服薬・食事の管理等の疾病の 自己管理と再発予防に必要な支援を重要としており，心 不全患者の予後を見据えた適切な支援を重視しているこ とがわかった。

一方で理学療法士群に「不要」とされた退院支援の上 
表 4 カード点数（中央值）

\begin{tabular}{|c|c|c|c|c|c|c|}
\hline 分類 & カード項目名 & 心不 & 全患者群 & 理 & 学療法士群 & \\
\hline & 1 心不全の一般知識 & 0.5 & $(-0.3 \sim 3.0)$ & 2.5 & $(1.8 \sim 3.0)$ & \\
\hline 疾患の説明 & 2 患者本人の病状説明 & 2.0 & $(0.8 \sim 3.0)$ & 2.5 & $(1.8 \sim 4.0)$ & \\
\hline & 3 心不全の予後説明 & 1.0 & $(-0.3 \sim 3.3)$ & 2.0 & $(1.0 \sim 4.0)$ & \\
\hline & 4 喫煙・飲酒のリスク説明 & -1.0 & $(-2.3 \sim 0.3)$ & 0.0 & $(-1.0 \sim 0.3)$ & \\
\hline 生活指道 & 5 適切な生活様式 & 2.0 & $(-0.3 \sim 3.0)$ & 2.0 & $(1.0 \sim 2.0)$ & \\
\hline 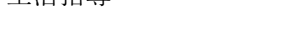 & 6 感染症予防 & 2.0 & $(-1.0 \sim 3.0)$ & 0.0 & $(0.0 \sim 1.0)$ & \\
\hline & 7 再発時の対処 & 3.0 & $(2.0 \sim 4.0)$ & 3.0 & $(2.0 \sim 4.0)$ & \\
\hline & 8 運動の効果 · 目的 & 0.0 & $(-1.0 \sim 0.0)$ & 2.0 & $(1.0 \sim 3.0)$ & $* *$ \\
\hline & 9 リハビリ目標 & 0.5 & $(-1.0 \sim 1.0)$ & 1.0 & $(0.0 \sim 2.0)$ & \\
\hline 理学療法の説明 & 10 リハビリ予後 & 1.0 & $(-0.3 \sim 1.0)$ & 0.0 & $(0.0 \sim 1.0)$ & \\
\hline & 11 退院後のリハビリ & 0.5 & $(-1.0 \sim 2.0)$ & 1.0 & $(0.8 \sim 2.3)$ & \\
\hline & 12 運動のリスク & 1.0 & $(-1.3 \sim 2.0)$ & 3.0 & $(1.8 \sim 3.3)$ & $*$ \\
\hline & 13 食事動作 & -2.0 & $(-3.0 \sim-1.0)$ & -3.0 & $(-3.3 \sim-1.0)$ & \\
\hline & 14 整容動作 & -2.0 & $(-3.0 \sim 0.0)$ & -3.0 & $(-3.0 \sim-1.8)$ & \\
\hline & 15 移乗動作 & 0.0 & $(-2.3 \sim 1.0)$ & -2.0 & $(-3.0 \sim-2.0)$ & $*$ \\
\hline & 16 更衣動作 & -1.5 & $(-2.0 \sim 0.0)$ & -2.0 & $(-3.0 \sim-1.8)$ & $*$ \\
\hline 日常生活活動について & 17 入浴・清潔 & 0.0 & $(-2.3 \sim 1.3)$ & -1.0 & $(-1.0 \sim 0.0)$ & \\
\hline & 18 トイレ動作 & -0.5 & $(-2.0 \sim 0.3)$ & -2.0 & $(-3.0 \sim-2.0)$ & $* *$ \\
\hline & 19 排泄管理 & -1.0 & $(-2.0 \sim 0.0)$ & -2.5 & $(-3.0 \sim-2.0)$ & $*$ \\
\hline & 20 歩行 · 移動 & 0.5 & $(-0.3 \sim 2.0)$ & 0.0 & $(-1.0 \sim 0.3)$ & \\
\hline & 21 階段動作 & 0.0 & $(-1.3 \sim 0.3)$ & -1.0 & $(-1.3 \sim 0.0)$ & \\
\hline & 22 退院前カンファレンス & 0.5 & $(-1.0 \sim 2.0)$ & -1.0 & $(-2.0 \sim 0.0)$ & $*$ \\
\hline & 23 自宅環境整備 & 0.0 & $(-2.0 \sim 1.0)$ & 0.0 & $(-1.0 \sim 0.3)$ & \\
\hline & 24 介護者の健康状態 & 0.0 & $(-1.0 \sim 1.0)$ & 0.0 & $(-0.3 \sim 1.0)$ & \\
\hline 退院調整 & 25 福祉用具 & -0.5 & $(-2.3 \sim 1.0)$ & -2.0 & $(-3.3 \sim-1.0)$ & $*$ \\
\hline & 26 介護サービス & -0.5 & $(-2.0 \sim 1.0)$ & -1.0 & $(-2.0 \sim 0.0)$ & \\
\hline & 27 自宅を想定した ADL 訓練・指導 & 0.0 & $(-2.3 \sim 1.0)$ & 1.5 & $(0.0 \sim 2.0)$ & $*$ \\
\hline & 28 介護事業所への引き継ぎ & -1.0 & $(-2.3 \sim 0.0)$ & -3.5 & $(-4.0 \sim-1.8)$ & $* *$ \\
\hline & 29 社会復帰 & -1.0 & $(-2.0 \sim 0.3)$ & 0.0 & $(-1.0 \sim 2.0)$ & \\
\hline 生活の庆がりと社会復侵 & 30 趣味活動 & -0.5 & $(-2.3 \sim 0.3)$ & 0.0 & $(0.0 \sim 1.0)$ & \\
\hline 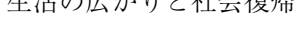 & 31 外出 $\cdot$ 交通機関の利用 & -0.5 & $(-2.0 \sim 0.0)$ & -1.0 & $(-1.3 \sim 0.0)$ & \\
\hline & 32 社会的課題解決 & -0.5 & $(-2.3 \sim 1.0)$ & 0.0 & $(-2.0 \sim 0.0)$ & \\
\hline 服薬管理 & 33 薬に関する説明・指導 & 1.5 & $(0.0 \sim 3.0)$ & 2.0 & $(1.0 \sim 3.0)$ & \\
\hline 栄養管理 & 34 食事に関する説明・指導 & 2.5 & $(0.8 \sim 3.3)$ & 2.5 & $(1.8 \sim 3.0)$ & \\
\hline 精神面へのサポート & 35 精神面へのサポート & 0.5 & $(-1.0 \sim 2.0)$ & 0.0 & $(-1.0 \sim 0.3)$ & \\
\hline
\end{tabular}

中央值 (四分位範囲). $*: \mathrm{p}<0.05, * *: \mathrm{p}<0.01$.

位 5 項目は「整容動作」,「病院と介護事業所の引き継 ぎ」，「食事動作」，「排泄管理」，「福祉用具の準備・使用 法」であった. 本研究の対象は心不全初回入院かつ入院 前の ADL 能力が自立している者であり，ADL・介護保 険・福祉用具に関する支援は不要とするのは当然と考え られる。この点においては対象の病期に適した判断であ ると考えられる。

患者群と理学療法士群はともに「再発時の対処」が重 要と考えながらも, その他の項目において差異も認め た. 心不全患者を含め心疾患に対する適切な運動処方に 基づいた運動の効果は身体機能の向上のみならず再発予 防に効果がある. しかし本研究の結果では, 理学療法士 群に比べ患者群の運動に関する支援のニーズは低かっ
た. 本研究の対象は入院後 2 週間以内の患者であり, 急 性期の段階において運動の効果に関する知識不足がある こと，または運動はリスクになるという偏った認識が影 響している可能性がある.

本研究の結果から心不全初回入院患者 - 担当理学療法 士が患者本人にとって必要と考える退院支援についてそ の特性と差異が明らかになった。 心不全患者は高齢者が 多く再発を繰り返す特徵がある。六不全患者にとって必 要な退院支援に関する報告はわずかに散見されるが，い ずれも症例報告や活動報告, 少数例からインタビューす る質的記述研究が主である。 また, 心不全治療のガイド ライン 13)や心蔵リハビリテーションの観点から，心不 全患者に対して提供するべき一般的な支援項目などは多 
くが述べられているが, 心不全患者の病期や属性に応じ て必要となる退院支援は何かという系統的な調査はされ ていない. 本研究は $\mathrm{Q}$ 分類という測定手法を使用する ことで多くの退院支援項目を優先順位に応じて並び替え， 心不全初回入院患者の「必要」または「不要」とするよ うな退院支援に関する価值観の全体像を包括的に調査し て捉えるという点において意義がある.

$\mathrm{Q}$ 分類は強制分類法で項目を優先順位に並び替えると いう方法で結果を得る. また, 点数を強制的に正規分布 させる特徵がある。 そのため, Q 分類ではカードの点数 は他のカードの点数との相対的な順序を示しており, 絶 対評価としての重要度を示さない. Q 分類では点数によ

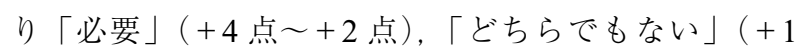
点〜 -1 点), 「不要」 ( -2 点〜 -4 点) のカテゴリに分 類されるが, 前述の理由からカード点数の平均点などを 代表值として分析する場合には，その代表値は相対評価 から成り立っていることになり, その解釈には課題があ る.これは $\mathrm{Q}$ 分類という測定手法を使用するうえで解 決することのできない限界と言える.

本研究では交絡因子をコントロールするために診断名, 年齢, ADL レベル, 認知症の有無などについて適合基 準, 除外基準を設け, 研究対象者の基本属性などを設定 した.しかし，入院中において患者や家族が医師，看護 師，管理栄養士などから受けた説明や指導は個々にばら つきがありコントロールできていない. また, 理学療法 士群は繰り返しの参加があり対象者個人の偏った価值観 がデー夕に影響していることを否定できない. そのため， 少なからずこれらの交絡因子が結果に影響を与えている 可能性はある。この点について退院支援としての取り組 みを均質にすることや制限することは現実的ではなく, 本研究の限界と言える。

本研究では $\mathrm{Q}$ 分類という測定手法を使用して心不全 患者本人と担当理学療法士のそれぞれが必要と考える退 院支援について系統的な調査をした，本研究の結果は心 不全初回入院患者が心不全に関する説明や再発予防のた めの支援を必要としている一方で，入院前 ADL が自立 していることを反映し, ADL, 介護保険, 福祉用具な どに関する支援は必要としないことが確認できた。また， 本研究の結果から理学療法士は「運動の効果・目的」や 「運動のリスク」の説明・指導を十分に行い再発予防に 努めることを入院期間中に説明・指導する必要があるこ とが示唆された。

利益相反 本研究に関して著者らが開示するべき利益相 反関係にある団体・企業はない.

謝辞 本研究の被験者となった患者, 家族, 理学療法士 の皆様のご協力により貴重な情報を収集し分析すること ができました。 また，研究実施を許可して下さった研究
実施施設と, その循環器内科医師, 理学療法士の協力に より円滑に研究を進めることができました，本研究を実 施するため $\mathrm{Q}$ 分類という特異的な調査・分析手法を使 用するにあたり茨城県立医療大学の上岡裕美子教授から の資料提供やご指導を頂きました。 また計画段階から解 析・執筆まで隆島研吾教授, 高木峰子准教授, 島津尚子 准教授には丁寧に多くのご指導を頂きました。ご協力い ただいた皆様に厚く御礼申し上げます。

\section{引用文献}

1) 厚生労働省大臣官房統計情報部：平成 26 年患者調査（傷 病分類編 ). https://www.mhlw.go.jp/toukei/saikin/hw/ kanja/10syoubyo/dl/h26syobyo.pdf（閲覧日2018年7月 5日）.

2) Tsutsui $H$, Tsuchihashi $M$, Kinugawa $S$, et al.: Clinical characteristics and outcome of hospitalized patients with heart failure in Japan: National and design of Japanese Cardiac Registry of Heart Failure in Cardiology. (JCARE-CARD). Circ J, 2006, 62: 95-101.

3) Shiba N, Watanabe J, Shinozaki T, et al. CHART Investigators: Analysis of chronic heart failure registry in the Tohoku district: third year follow-up. Circ J, 2004, 68: 427-434.

4) Shiba N, Nochioka K, Miura M, et al. CHART-2 Investigators: Trend of westernization of etiology and clinical characteristics of heart failure patients in Japan-first report from the CHART-2 study. Circ J, 2011, 75: 823-833.

5) 若林昌司, 廣澤隆行, 吉田真美・他：当院における心不全 サポートチームと心臓リハビリテーション. 理学療法の臨床 と研究, 2012, 21: 29-33.

6) 葛西好美, 荒賀直子, 樋口キエ子・他：高齢者急性期病院 に㧍ける患者・家族の退院に向けた関わりへの一考察. 医 療看護研究, 2007, 3: 96-101.

7) 永田智子, 村嶋 幸代 : 高齢患者が退院前・退院後に有する 不安·困り事とその関連要因. 病院管理, 2007, 44: 323335.

8) 河井丈幸, 安藤良美: 回復期リハビリテーション病棟にお ける患者・家族が退院前に感じる不安の要因に関する研究— 入院患者・家族へのインタビュー調査を通して. 日本看護 学会論文集, 2013, 2: 39-42.

9) 岡本伊織：Q分類法による価値観の測定一いかに捉えづら いものと捉えるか一. 赤門マネジメント・レビュー, 2011， 10: 851-877.

10) Stephenson W: The study of behavior: Q-technique and its methodology. University of Chicago Press, Chicago, 1953.

11) Tsuchihashi M, Tsutsui H, Kodama $K$, et al.: Clinical characteristics and prognosis of hospitalized patients with congestive heart failure-a study in Fukuoka, Japan. Jpn Circ J, 2000, 64: 953-959.

12) Goodlin SJ: Palliative care in congestive heart failure. J Am Coll Cardiol, 2009, 54: 386-396.

13) 日本循環器学会 ·日本心不全学会合同研究班: 日本循環 器学会／日本心不全学会合同ガイドライン。急性・慢性 心不全診療ガイドライン (2017年改訂版). https://www. mhlw.go.jp/file/05-Shingikai-10901000-KenkoukyokuSoumuka/0000202651.pdf(閲覧日2018年7月 5 日). 